\title{
日本の纎維産業の将来
}

\section{Forecast of Japanese Fiber Industry}

長 島徹

\section{1.はじめに}

瀻維産業はこの 100 年で大きく変わった。綿、麻、羊毛 といった天然繊維だけの時代から、レーヨン、更には、ア クリル、ナイロン、ポリエステルといった合繊が加わり、 多様な繊維製品を作り出してきた。歴史は西に進むという 説がある。イギリスに始まった近代的な繊維産業はアメリ カに伝わり、先の後、日本、韓国・台湾、そして、中国、 さらにインドと地球上を西に回って移動するという説であ る。代表的な合成繊維であるポリエステル繊維も西に向 かって動いている。本格的な生産はイギリスで始まったが、 現在のメーカー別生産量ランキングを見ても、欧米メ一 カーの名前はない。繊維産業は元来、労働集約型であり、 製造設備メーカーのノウハウがあれば安い賃金を求めて動 き易い産業である。それに加えて、欧米企業に長期的視点 が欠けて打り、環境の変化に対応して、新市場を育てる努 力が足りなかった事も主要な生産者が西に動いて行った一

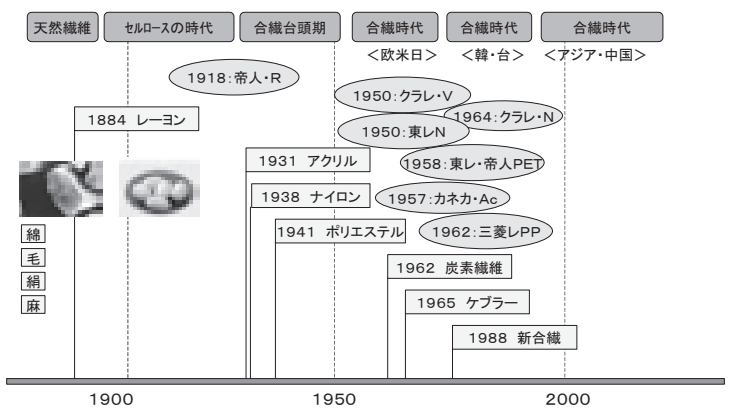

図 1 繊維産業 100 年の歴史

因ではないかと考えている。

それでは日本の繊維産業はどうであろうか。図 2 は 1950 年から日本の主要䋐維製品の生産量を示したものである。 1950 年頃から天然繊維やセルロース繊維を中心に急速な

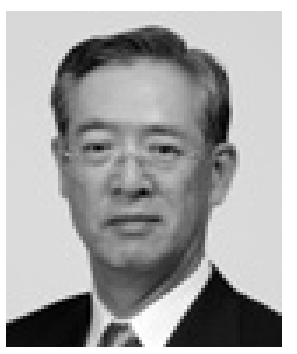

TORU NAGASHIMA

帝人株式会社 代表取締役社長

○100-8585 東京都千代田区内幸町2-1-1

Tel : 03-3506-4042 Fax : 03-3506-4046

〈趣味〉テニス、ゴルフ、ウォーキング

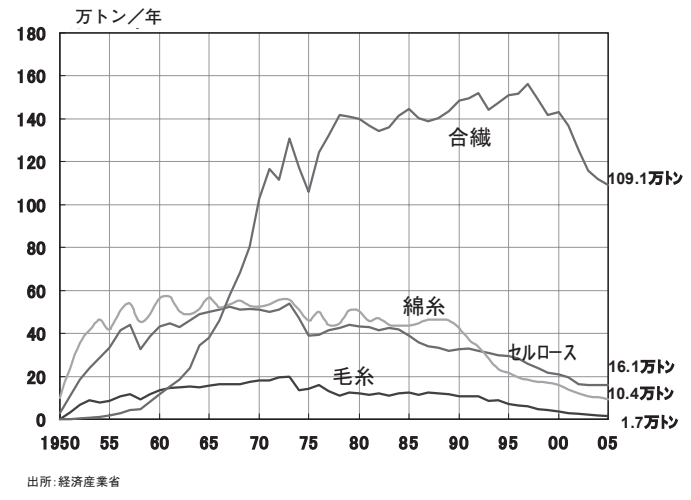

図 2 日本の主要繊維製品の推移

復興を果たしたが、 60 年代から合繊が成長の主役となり、 70 年代、 80 年代は他繊維の生産量が減少する中でも増加 を続けた。その背景には新合繊に代表される日本独自の商 品開発や、産業資材等新規用途開拓があった。しかし、90 年代後半からは明らかに違った傾向が見られる。経済産業 省「工業統計」によると繊維製品の出荷額は 1998 年 91,672 億円から 2003 年には 55,888 億円と $61 \%$ となった。これ らの繊維産業に携わる従業員数も 835 千人から 514 千人と なって打り、この 5 年間で産業の規模が概ね 4 割縮小する という危機的な状況となっている。この大きな要因は近隣 諸国、特に中国の生産力の増大によって、相対的な競争力 が低下した事、それに伴う、製品を中心とした輸入の増加 である。日本の繊維産業はこのまま衰退するのであろうか。 私はそうは思わない。日本の繊維産業は欧米と違った歩み をするのではないかと考えている。

\section{2. 日本の繊維産業に見る成功例}

日本の繊維産業は長い間、世界をリードしてきた。特に 商品開発は日本が得意とする分野で、これまでにも、いく つか大きな成果が見られる。その代表的な例として(1)人工 皮革、(2)中空繊維を使った水処理フィルター、(3)炭素繊維 がある。人工皮革は 1964 年に米国 DuPont 社が開発に成 功したものであるが、その後、日本メーカーが独自の糸つ くり、不織布技術、後加工技術との組み合わせによって新 たな価值を加え、靴や鞄といったそれまでの用途から衣料 用途やインテリア・資材用途へと飛躍的に需要を拡大させ た。中空糸による水処理フィルターも、商品開発はかなり 古くから行われていたが、なかなか市場が広がらなかった。 


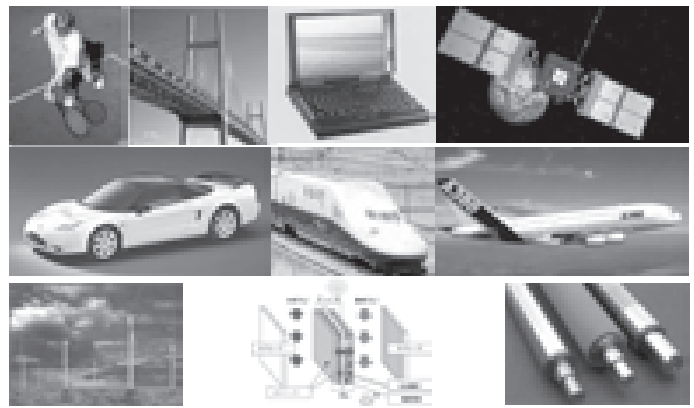

日本の成功例：炭素繊維

その後、長年に亘る高度な紡糸技術を活用した糸開発、工 ンジニアリング面の改良によって、今では最も将来性のあ る商品の一つに成長した。水の世紀と言われる 21 世紀に は不可欠な商品として世界から注目されている。炭素繊維 も長い間、夢の繊維と言われていたが、釣竿やスポーツ用 品程度しか用途がなく、生産量は僅かなものであった。し かし、粘り強い商品開発の結果、軽量化・省エネ化の追い 風もあって、近年、急速に用途拡大が進んだ。特に、カー ボンコンポジットに代表される航空機分野等へと拡大し、 先端技術商品に直結する繊維素材として需要拡大期を迎え ている。

これらの成功事例に共通していることは、時代が要請す るニーズを的確に捉えている事、中長期的な経営視点から、 地道な技術・商品開発を継続して推進している事、これま での繊維の枠組みに囚われず、他素材との複合や、周辺業 界との連携によって新たな市場を獲得している事等である。

\section{3. 日本の繊維産業の可能性}

これからの日本の繊維産業を考える場合、そのキーとな るのは「量重視から質重視への転換」である。今後、目指

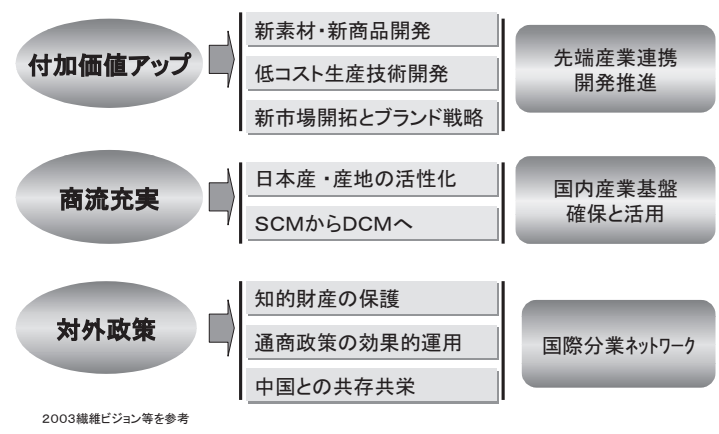

図 3 日本の繊維産業の方向性

すべき方向性を図 3 に示した。まず重要な事は更に付加価 值を高める事である。具体的には新素材・新商品開発、低 コスト生産技術開発、新市場開拓やブランド戦略による価 值向上等だ。これらを推進する為には先端産業との連携や、 産学協働を進める事等、幅広い情報収集や連携が欠かせな い。二番目は商流の充実である。生産されたものが途中で 滞ることなく、効率よく消費者の手に届くシステムが必要 である。その為には、国内の産地を活性化し、素材を製品 にする生産基盤を確保すると共に、生産者主導の SCM
(Supply Chain Management)を一歩進めて、顧客ニーズを 的確に捉え、売れる商品を確実に提供する DCM(Demand Chain Management)が求められている。三番目は有効な対 外政策である。日本の䋊維産業はもはや海外を無視しては 成り立たない。国内で開発された技術の保護や、FTA·EPA の戦略的な活用、WTO で認められた不公正貿易対抗措置 の適正な運用等、的確な通商政策の推進、更に、中国等海 外の安い労働コストを活用し共存共栄を図る事によって国 際的な分業ネットワークを構築する事等が目指すべき方向 である。

これらを実現するためには、コモディティとは違った固 有技術による生産・設備・ノウハウや、素材、後加工、技 術の複合化によって他の国には出来ない継続的な新素材・ 新商品開発を活発化させる事が出来るかがポイントである。

日本には伝統に基づいた繊維技術の蓄積、成熟した社会、 洗練された豊かな消費市場、世界をリードする先端産業の 集積がある。また、現代は変化の時代である。多種多様な 価值観の変化や、国内における少子高齢化、地球環境問題 等の進展が新たなニーズを顕在化させる。これら日本繊維 産業が置かれた有利な位置を活用し、長期的な視野を持つ て、独自の技術を磨き、時代が要求するニーズに的確に対 応すれば、これまでにない価值を創造し、市場が満足する 商品を素早く提供する事が出来る。先に述べた過去の日本 の成功例は、正にこれらを実践した例であり、更に進化さ せて行けば大きな可能性が開けると確信する。日本の近代 的繊維産業の歴史は 1 世紀半に達し、いわばオールドエコ ノミーに属しているが、この様に考えると、所謂、ニュー エコノミーへの転換は、繊維産業では日本が最も可能性が 高いのではないかと思われる。

\section{4. 繊維産業のフロンティア}

今後、日本の繊維産業にとって新たなフロンティアはど のようなものであろうか。私は以下の 3 つを上げたい。 第一に、ナノテクノロジーである。カーボンナノチューブ は自由自在な形状が得られるまでに進化している。今後の 課題は、この先端素材・技術を生かした用途開発である。 ポリエステルナノファイバー等も開発が進んでいる。素材 の開発と並行して、特性を最大限に生かす加工技術の革新 も必要であるが、まったく新しい感性を持ったテキスタイ

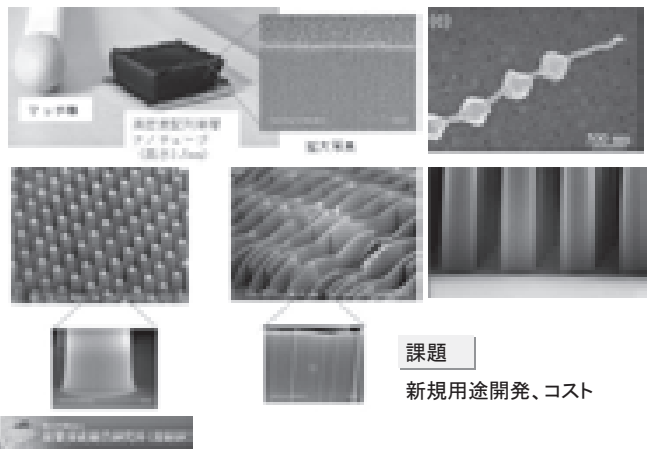

カーボンナノチューブの進化 
ルや、機能を高めたフィルター等期待される用途も多い。 今後、これらの新たな素材が連鎖反応を起こし、周辺の技 術革新を促進し、まったく新しい分野を切り開く可能性が 高いと思っている。

第二は、環境・エネルギー分野への対応である。環境を 重視する成熟した社会では緊急度の高い課題となっており、 繊維にとっても大きな可能性がある分野である。例えば、 地球温暖化は最近益々深刻化し、日本では社会の関心も高

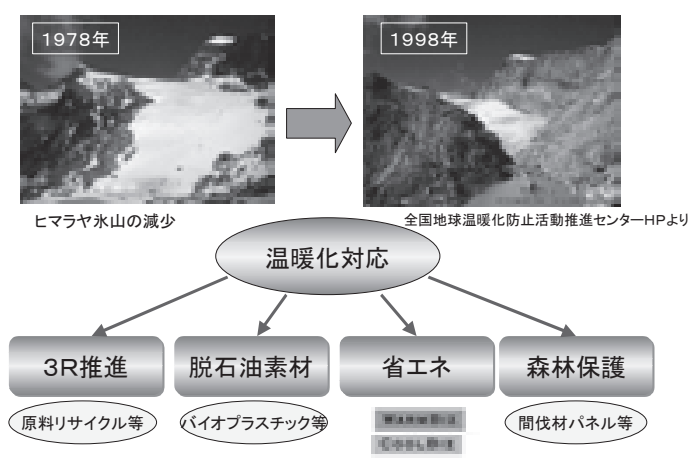

温暖化の実態とその対応
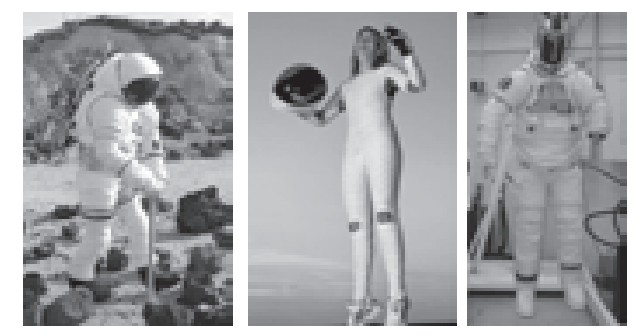

NASA 開発新型宇宙服

い問題であるが、 $\mathrm{CO}_{2}$ 削減を目指した省エネに関連して クールビズ、ウォームビズが新たな需要を掘り起こした事 は記憶に新しい。これ以外にも $3 \mathrm{R}$ 推進に関連してリサイ クルに対する要請の増大や、脱石油としてバイオプラス チック・バイオ繊維、森林保護に関連して、新たな繊維資 材の拡大が期待される。また、環境対策として開発・改良 される商品が新たなニーズを顕在化させる。例えば省エネ を目指した自動車の開発は繊維にとっても新たなフロン ティアになる。

第三は、全ての分野に共通することだが、周辺産業・技 術との融合、すり合わせの分野である。例えば、衣料分野 と産業資材分野が求める機能は夫々固有のものであるが、 これらの融合によって、新たな用途・市場が出来る可能性
が高い。現在、開発が進められている次世代宇宙服等はそ の典型である。耐熱性、バリアー性、高強度、作業性といっ た視点での素材開発と素材複合、また、IT工学、生命工 学、宇宙工学、医学、放射線制御と言った多くの産業、技 術の融合が宇宙で快適に過ごせる環境を提供する事を可能 にすると共に、その技術が他の分野にも転用され新たな機 能として需要を拡大させる。実は、日本人はこの融合・す り合わせを世界中で最も得意とする国民性ではないかと 思っている。競争力の強い産業は融合 -すり合わせ技術に よるところが多い。これから日本纎維産業の発展には欠か せない視点である。

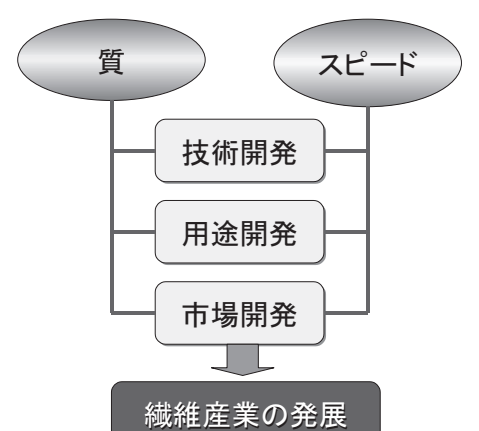

図 4 繊維産業発展のキーワード

\section{5. 日本繊維産業発展のキーワード}

以上が、私の日本の繊維産業に対する認識である。今、 最も必要な事は絶え間ない技術開発や用途開発、それに市 場開拓である。更に、私はこれら 3 つを推進するべースに 「質」と「スピード」を上げたい。高い「質」を伴う開発 によって、産業の発展に大きなインパクトを与えることが 出来る。現在の日本繊維産業は高い「質」を維持している が、継続的に「質」を高めるには高品質・高機能へのこだ わり、技術の伝承といった人的な要素が重要である。これ からの日本の繊維産業にとって人材の問題は避けて通れな い大きな課題である。産官学が協同した人材育成が望まれ る。また、新たな商品が開発され、事業が成長するには、 タイミングが必要である。どんなに進んだ技術でも時期を 冕すれば、単なる自己満足に終わる。これまでの日本企業 は欧米企業に比べて、スピード感に欠けるところがあると 言われている。日本繊維産業は更に「スピード」を意識し た開発が重要である。この「質」と「スピード」が十分に 備わった時、技術・用途・市場開発は三位一体のものとな り、日本の繊維産業は新しい時代に対応した産業として、 これからも大きく発展して行くと確信している。 